\title{
The Inclusion of Health in County Comprehensive Planning
}

\author{
Sang Chul Park,* Christopher Coutts** and Se-Jin Lee***
}

\begin{abstract}
This article explores what drives communities in United States to include health objectives in their comprehensive plans. By using a place-based approach, this model is able to take into account variables such as health status, social equity, political institutions, and built environment. The findings suggest that communities are more likely to adopt health as a goal based on their political institutional structure and environmental quality (e.g., air pollution) than based on health status and social equity factors. Therefore, communities are responding to poor health and heightened mortality per se but rather to environmental factors that are associated with poor health outcomes.
\end{abstract}

Keywords: Public health, comprehensive plans, place-based population health

\section{INTRODUCTION}

It has been decades now since planning and public health have rediscovered their shared goals. This relationship has evolved to a point where the built environment is now accepted as integral to a holistic and ecological view of community health (Sallis, Owen, \& Fisher, 2008). Most of the built environment and health research over the

* Sang Chul Park is an assistant professor in the Department of Public Administration at Yeungnam University. His research interests include the intergovernmental relation, smart and sustainable development, health and urban policy and official development assistance. E-mail: scpark@ynu.ac.kr.

** Chris Coutts is an associate professor in the Department of Urban and Regional Planning at Florida State University. His research interests include planning for healthy and resilient communities, human settlements and institutions in the context of global change. E-mail: ccoutts@fsu.edu.

*** Se Jin Lee, corresponding author, is a Ph.D from the Askew School of Public Administration and Policy at Florida State University. Her research interests include hierarchical and local governance, environment and urban policy and intergovernmental relations. E-mail: sejinl@hotmail.com.

Manuscript received February 10, 2014; out for review March 3, 2014; review completed March 31, 2014; accepted April 2, 2014.

The Korean Journal of Policy Studies, Vol. 29, No. 1 (2014), pp. 1-20.

(C) 2014 by the GSPA, Seoul National University 
past two decades is reflective of the realignment of planning and public health and has focused on associations between built environment variables and health outcomes. This has led to a number of communities to include explicit health provisions-such as proposals for creating pedestrian environments and for adapting to climate changein their long-range comprehensive plans. Though sometimes controversial, these plans aim to contribute to the creation of an environment supportive of health and enhancing behaviors by including attributes of the built environment.

Though planners have actively engaged in health planning, they have not by and large taken up the question of what factors lead communities to include health provisions in their comprehensive plans, which is subject of this article. Specifically, we considered whether community health status is a factor. Are health provisions included in plans to remedy ills or to simply maintain an already healthy community, and what types of environmental conditions are planners addressing?

Our study tested the effects of place-based population health status on the adoption of comprehensive plans for public health improvement. While previous studies have concentrated on public health policy choices and public health management guided narrowly by factors relating to socio-demographic status, our research expanded the scope of factors, taking into account such variables as physical environment, clinical care, and health behavior, which allowed us to test the policy endogeneity of the adoption of comprehensive plans and to investigate whether or not an expansion of comprehensive plans to include public health provisions is dependent on measurable community needs.

This study using the following three steps to test for indicators of health in the comprehensive plan. First, this research tests if communities include health in their plans to ameliorate morbidity and premature mortality. Three aspects essential to health are tested. One of these is the equitable allocation of resources to the entire community and to those who arguably need them the most (Aytur et al., 2008). Are communities of lower socio-economic status and social support more likely to include health in their plans? Second, this research explores the role of local politics in the production of comprehensive plans that explicitly address public health. Understanding that collaborative actions and local governance determine the conflicts which are caused by various interests in future community development (Corburn, 2009; Portney, 2003; Graham and Marive, 2001; Fishman, 2000), we explore whether the political institutions more likely to consider long-term interests are more likely to include health in their plans. Third, a number of aspects of the physical environment are examined to determine if health is included in plans to remedy these deficiencies.

This paper begins with a discussion of health in comprehensive planning. This plan serves as the vision for guiding the structure and function of place. This is followed by 
a description of place-based health. The composition, context, and collectivity specific to place are integral to understanding place effects on health (Macintryre, Ellaway \& Cummins, 2002). This research posits that place-based effects are captured through an examination of equity, political institutions, and environment. The methods and results sections are followed by our conclusion that local political institutions and air quality are significant factors predictive of the inclusion of health provisions in county comprehensive plans.

\section{HEALTH IN THE COMPREHENSIVE PLANNING}

The inclusion of health in the comprehensive plan can be traced to the original legal justification for planning in the United States (Schilling \& Linton, 2005). The seminal 1926 Supreme Court case Village of Euclid v. Ambler Realty Company made zoning constitutional as a commercial structure was prohibited from being built in a residential zone (Levy, 2012). Thus, zoning was viewed as a tool to separate land uses in an effort to prevent public nuisance with potential public health ramifications. In fact, it is the protection of public health and welfare that provides the basis of many state police and regulatory powers. This had been often forgotten or obscured until the movement to create more "active environments" gained momentum in the 1990s. This movement, fueled by a diverse set of stakeholders, has spurred many communities to include elements of livability and walkability in their plans.

In these types of plans, health measures are either dispersed throughout various sections (i.e., Brevard County in Florida; Blair County in Pennsylvania) or else are addressed in a section dedicated to health (i.e., Baltimore County, Maryland; Scott County, Minnesota). These plans not only encompass environmental components but also take up newly emergent public health issues, such as long-term health care, health equity, climate change, clean water and air, and physical activities (APA, 2011).

If comprehensive plans are intended to guide future community development, promoting efficiency and social, physical, and economic well-being (Kelly \& Becker, 2000), then since health is an obvious indicator of how well communities are planning, one would except health measures to figure in such plans. A comprehensive plan that addresses public health recognizes urban development patterns and public health concerns by seeking the input of a variety of stakeholders, sectors, and organizations. Therefore, the public health criteria chosen by a local government reflect the urban environment and policy priorities (Schively, 2007) as well as the conflicts between the various interests of local stakeholders (Downs, 2005). Conflicts are inevitable because smart growth practices must be balanced by economic development, the accessibility 
of public health to wide range of groups in the community, and environmental protection. The politics of urban planning processes calls for multidisciplinary cooperation, administrative collaboration, and a consensus-building effort among professionals and the community. Though successful planning efforts foster these key components, traditional planning processes are often criticized heavily for engendering political fragmentation.

At times, planning processes focus on balancing out the competing interests of narrowly organized groups rather than on serving the interests of the entire population (Kelly \& Beck, 2000). A city health plan to enhance the health status of the population requires social and political commitment (Corburn, 2009).

\section{PLACE-BASED HEALTH}

Place-based population health is reflected in new urbanist, smart growth, and sustainable community ideals that emphasize the interaction between the physical environment and social conditions (Cummins et al., 2007). Socio-physical conditions strongly impact public health, and when communities fail to build sustainable sociophysical environments, mortality and morbidity increase (Haan, Kaplan, \& Camacho, 1987). Local governments must plan for social and physical environment that result in positive public health outcomes if they wish their communities or cities to be healthy. In 1986, health professionals at the World Health Organization (WHO) meeting in Copenhagen first conceptualized the idea of the healthy city. A healthy community can be broadly characterized as one that promotes public health strategies including medical treatment and personal disease to a community that supports the creation of 'healthy' physical environment corresponding with the social, economic, and environmental determinants (Hancock, 1993). Urban planning with a public health emphasis shapes better places and builds communities' assets for public health improvement (Minkler, Wallace, \& McDonald, 1995). The healthy city idea expanded the public health focus on immunization and intrapersonal determinants of diseases and stressed creating healthy physical environments that would help prevent disease in the first place. Integrating these two components, it was thought, would produce a healthy community with a high quality of life and heightened well-being (Price \& Dube, 1997). Public health improvement is viewed as a prerequisite for sustainable community development.

This research discusses three components of a place-based approach. These are the extent of social justice in the community, the nature of the political institutions in the community, and the community's environment (Duhl \& Sanchez, 1999). These 
components are tested in this study by exploring whether persons that need resources the most are receiving them (Aytur et al., 2008), whether the political structure of a community influences its responsiveness to community needs (Corburn, 2009; Portney, 2003; Graham and Marive, 2001; Fishman, 2000), and whether characteristics of the physical environment play a role in making health an explicit goal of comprehensive plans. Are communities with a lower socio-economic status and weaker social support more likely to include health in their plans? Are political institutions that take longterm interests into account more likely to include health measures in their plans?

Many studies of social environment and population health find that the nature of specific places significantly impacts the kinds of human activity that are undertaken in them, and many scholars argue that the effects of place are not simple but dynamic and complex processes, such that, for example, individual health behaviors come to be embedded in the neighborhood environment (Macintyre \& Ellaway, 2000; Yen \& Syme, 1999). Macintyre, Ellaway and Cummins (2002) point out that population health research fails to integrate the features of composition- which explain the individual characteristics, context- which presents physical structure and collectivity- which implies social support. There is of course intrinsic overlap in these concepts, but in the majority of public health research, these three dimensions are addressed or investigated as mutually exclusive determinants. However, Macintyre and her coauthors treat these dimensions as interrelated and show how population health is achieved by the interaction among compositional, contextual, and collective characteristics as well as individual health behaviors.

The social equity, political institution, and physical environment criteria employed in this study reflect the theoretical frames identified in the WHO healthy cities cross over nicely with Macintyre's concepts. Equity can be captured in different ways (Talen, 1998), but all measurements are dependent upon understanding composition and who is receiving or being denied resources. The physical environment is critical to understanding context, and political institutions are an aspect of collective decision making. This study adds to our knowledge of whether planners, and others involved in comprehensive plan creation, are responsive to these compositional, contextual, and collective aspects of a healthy city.

Since current social determinants of public health vary by interactive processes of composition, context and collectivity, plans must acknowledge the relative differences of existing physical environments and establish multiple meanings or methods for public health improvement (Graham \& Healey, 1999). Thus, the perspective of placebased population health is an important factor in the creation of comprehensive plans (Healey, 1996). 


\section{Social Equity}

First, striving for social justice recognizes differences of social composition and position (Duhl \& Sanchez, 1999). In terms of the reality of unequal social positions and conditions, the society should have responsibility and accountability to solve the social segregation of health disparities. This perspective concentrates on the community's endogenous factors determining social health characteristics.

The extant population health perspective helps us to understand the perception of the relational site view. The basic objectives of the population health perspective are related to reducing mortality and increasing morbidity. Thus, the population health approach emphasizes the function of social circumstances, which negatively or positively influences population health status (Young, 2006). The population health approach recognizes that health inequalities are derived from distributional differences of material resources and unequal social status (e.g. level of income, education) (Marmot \& Wilkinson, 2003; Link \& Phalen, 2000; Mishler, 1981). To improve population health we must understand "what explains the distribution of disease and well-being across populations" and "what drives current and changing patterns of inequalities in well-being across population groups" Corburn (2009, p. 97). Addressing these issues, Raphael (2006) emphasizes the connections between politics, social support, economic conditions, health behavior, and epidemiological approaches to promote population health.

\section{Political Institutions}

The comprehensive plan that takes into account various policy sectors is regarded as a sum of the preferences of local elected and appointed officials, who in turn are presumed to reflect the various interests of citizens and interest groups, and it can serve as a means for mediating conflicts in negotiations to reach an agreement. The classical perspective on comprehensive plans explains land use and urban planning by way of reference the rules of the growth machine politics under which pro-development interests groups as business elites are able to form strong political alliances and make local politicians pay attention to their preferences (Molotch, 1976; Park, Park, \& Lee, 2012). That is, under growth machine politics, planning decisions are made by local representatives who are interested in short-term policies such as economic development that benefit only certain citizens. The limited budget and resources of local governments are constraints that reduce their capacity to develop comprehensive plans that satisfy all citizens and other stakeholders.

However, modern local politics of urban planning expand the scope of the classical growth machine politics, taking into account interactive politics. While traditional 
planning processes admit their limitation in making decisions that take all community preferences into account, recent planning processes suggest that local elected representatives do have the capacity to achieve sustainable communities (Kelly \& Beck, 2000). Since the comprehensive plan is meant to represent urban structures, functions, and patterns, local governments should be willing sacrifice certain preferences of community, region, and even government itself in order to achieve urban plans that have a long-term vision. That is, a comprehensive plan can be either a product of a consensus of community preferences or of a resolution of the conflicts of disaccord (Moore, 1986). Thus, local politics can acknowledge pluralism and participatory processes in building a comprehensive plan rather than operating from the assumption of a single ideal actor (Gruber, 1994; Putnam, 1993).

In the public health sector, the political economic approach emphasizes the political alliances that influence public health resource allocation (Minkler et al., 1995) and the often unequal allocation of resources resulting from narrowly concentrated interests in public health. The politics of healthy city plans, in contrast to regional-wide policies, focus on place-oriented differences and population health status. Understanding the different types of county government is helpful in considering the politics of the healthy city. There are three general kinds of county governments: the commission form, the council-manager form, and the mayor-council form. The commission form, a classical form of local governance, is regarded as non-reformed type of county government, consisting of elected officials who are in charge of both administrative and legislative functions. This form suffers from susceptibility to the influence of political alliances such as interests groups and lobbyists and from political corruption. On the other hand, the council/manager and strong mayor forms are considered reformed types of local government that separate executive and administrative functions (Renner, 2001; Svara, 1990). In contrast to the commission form, the council/manager and mayorcouncil varieties of county government emphasize professionalism in administrative and executive functions and also seek to implement welfare and redistributive policies.

For instance, according to Fleischmann, Green, and Kwong (1992), an elected executive structure is more likely to produce more responsible and accountable land use and growth management policy. Downs (2005) and Orfield (1998) posit that administrative managers have tended to develop policies in accordance with preserving green spaces, while reformed county governments have embraced inner-county development in an effort to levy financial advantages for local budgets. Specific to health, Costich and Patton (2012) investigated the effect of reformed county governments on premature mortality. They found that poverty is associated with premature mortality but that efforts on the part of reformed county governments to address poverty reduce the premature mortality rate. This evidence might be related to the findings in the studies 
of Park (1996) and Feiock and Kim (2001), namely, that reformed county governments tend to increase expenditures for public services (for example, public safety), physical infrastructure, and traditional county services (firefighting, public health, and transportation, for instance). Thus, reformed county governments characterized by administrative professionalism and governmental accountability are more likely to advance comprehensive plans that address multiple objectives related to population health, community development, and environmental protection.

\section{Built Environment}

The ecological conception of health adopted in the healthy city movement recognizes that it is not only the compositional factors relating to who is getting the resources or the ability of our political institutions to deliver them that have an effect on health and health behavior but also socio-ecological processes in the physical environment. Neighborhood, physical, and ecological environments determine public health status, which is a cornerstone of the built environment (Ashton \& Ubido, 1991; Tesh, 1990). The ecological model has been critiqued for its lack of a truly ecological focus on the natural environment and ecological processes (Coutts \& Taylor, 2011), but it is still valuable as it recognizes the critical role the environment plays in determining health.

Most of the planning and public health literature over the past two decades has applied this model, whether explicitly or not, to examine the role of the built environment in facilitating or hindering physical activity. This research has provided mixed results of the influence of scale, structure, and design on physical. Receiving much less attention is the role of the built environment on the delivery of the basic elements of life (air, water, food). Even less has appeared on the subject of the sustainable delivery of these elements in the midst of climate change. The physical environment variables in this study that not only capture the importance of recreational facilities in supporting physical activity and other correlates of health but also of air and food quality.

\section{DATA AND METHODS}

The data for this study was collected from three sources. The first is the 2011 Comprehensive Planning for Public Health survey conducted by Planning and Community Health Research Center of the American Planning Association. The APA survey is distributed to planning directors and other local planning department staffs who engage in long-range planning at the local government level (APA, 2010. p. 5). This survey was the first step in the process of trying to develop local policies that promote public 
health and to identify the kind of comprehensive plan that could include public health elements. So because this survey analyzed local efforts to improve public health through local comprehensive plans, it has been influential. Our research utilizes the question of whether a jurisdiction adopts a comprehensive plan "containing explicit goals, objective, or policies that address public health" from this survey as dependent variable. 1 is used to indicate that a given county government adopted health measures in their comprehensive plans, while 0 is used to indicate that a given county government did not. A logistic regression model was employed in the analysis to accommodate the binary nature of the dependent variable.

The second source we used is the 2010 International City/County Management Association's Municipal Year Book. The Municipal Year Book is an authoritative source book for local governments in general. In particular, it documents the types and structures of local governments across the country. For measuring political institution as independent variable, reformed county government is focused and coded as dichotomy variable based on whether or not a county government is structured as either council-elected executive form or council-manager form.

The third source we used was the University of Wisconsin Population Health Institute's 2010 county health rankings, a production of collaboration between the institute and the National Association of County and City Health Officials We drew on its index to measure population health. The institute provides county health ranking and standardized health Z-scores identifying health outcome (i.e., mortality and morbidity) and health factors (i.e., health behaviors, clinical care, socioeconomic factors, and physical environment). All data for population health are continuous variables. Specifically, the standardized health scores are calculated using the following equation:

$$
Z=\frac{(\text { County Value })-(\text { Average of Counties in State })}{\text { (Standardized Deviation of counties in State) }}
$$

The z-scores are comparable across states since the data with respect to population health are consistently generated by applying the same criteria of population health. However, three indicators of health status, namely, adult obesity, physical inactivity, and sexually transmitted infections, produce different measures owing to different governance structures and health policies among states. Thus, we re-standardized the first set of standardized z-scores among sampled states using the following equation.

$$
Z=\frac{(\text { Sampled County Value })-(\text { Average of Sampled Counties among State })}{\text { (Standardized Deviation of Sampled Counties among State) }}
$$


We then compared the two sets of analytical results by z-scores within state and among samples states, which provided consistent statistical results. We conducted our actual using the initial $\mathrm{Z}$ scores. The $\mathrm{z}$ highest $\mathrm{z}$-score indicates the worst health status and the lowest score indicates best health status. Table 1 shows the comparability of population health across states and the index of population health. Tables 2 and 3, respectively, provide the description of model variables and the descriptive statistics of the counties sampled.

Table 1. Comparability of Population Health Across States

\begin{tabular}{|c|c|c|c|c|c|}
\hline \multicolumn{2}{|c|}{ Focus Area } & Measure & Comparable & $\begin{array}{c}\text { Not } \\
\text { Comparable }\end{array}$ & Notes \\
\hline \multicolumn{6}{|c|}{ Health Outcome } \\
\hline \multicolumn{2}{|l|}{ Mortality } & $\begin{array}{l}\text { Premature Death: Years of } \\
\text { potential life lost before age } 75\end{array}$ & V & & \\
\hline \multirow{4}{*}{\multicolumn{2}{|c|}{ Morbidity }} & Poor or fair health & V & & \\
\hline & & Physically unhealthy days & V & & \\
\hline & & Mentally unhealthy days & V & & \\
\hline & & Low birth weight & V & & \\
\hline \multicolumn{6}{|c|}{ Health Factors } \\
\hline \multirow{7}{*}{$\begin{array}{l}\text { Health } \\
\text { Behavior }\end{array}$} & Tobacco use & Adult smoking & V & & \\
\hline & \multirow{2}{*}{ Diet and Exercise } & Adult obesity & & V & \multirow{2}{*}{$\begin{array}{l}\text { Models include state-level influences that make } \\
\text { comparisons inappropriate }\end{array}$} \\
\hline & & Physical inactivity & & V & \\
\hline & \multirow{2}{*}{ Alcohol use } & Excessive drinking & V & & \\
\hline & & Motor vehicle crash death rate & V & & \\
\hline & \multirow[t]{2}{*}{ Sexual activity } & Sexually transmitted infections & & V & $\begin{array}{l}\text { Differences in screening rates may make } \\
\text { comparisons problematic even within some states }\end{array}$ \\
\hline & & Teen birth rate & V & & \\
\hline \multirow{5}{*}{ Clinical Care } & \multirow{2}{*}{ Access to care } & Uninsured & V & & \\
\hline & & Primary care providers & V & & \\
\hline & \multirow{3}{*}{ Quality of care } & Preventable hospital stays & V & & \\
\hline & & Diabetic screening & V & & \\
\hline & & Mammogram & V & & \\
\hline \multirow{7}{*}{$\begin{array}{l}\text { Social and } \\
\text { Economic } \\
\text { Factors }\end{array}$} & \multirow{2}{*}{ Education } & High school graduation & V & & Select states have state-based data reported. \\
\hline & & Some college & V & & \\
\hline & Employment & Unemployment & V & & \\
\hline & Income & Children in poverty & V & & \\
\hline & \multirow{2}{*}{$\begin{array}{l}\text { Family and social } \\
\text { support }\end{array}$} & Inadequate social support & V & & \\
\hline & & Children in single-parent & V & & \\
\hline & Community safety & Violent crime & V & & \\
\hline \multirow{5}{*}{$\begin{array}{l}\text { Physical } \\
\text { Environment }\end{array}$} & \multirow{2}{*}{ Air quality } & Air pollution-particulate matter days & V & & Comparable where reported \\
\hline & & \begin{tabular}{|l|} 
Air pollution-ozone days \\
\end{tabular} & V & & \\
\hline & \multirow{3}{*}{ Built Environment } & Limited access to healthy foods & V & & Alaska and Hawaii have a different data sources \\
\hline & & Fast food restaurants & V & & \\
\hline & & Access to recreational facilities & V & & \\
\hline
\end{tabular}




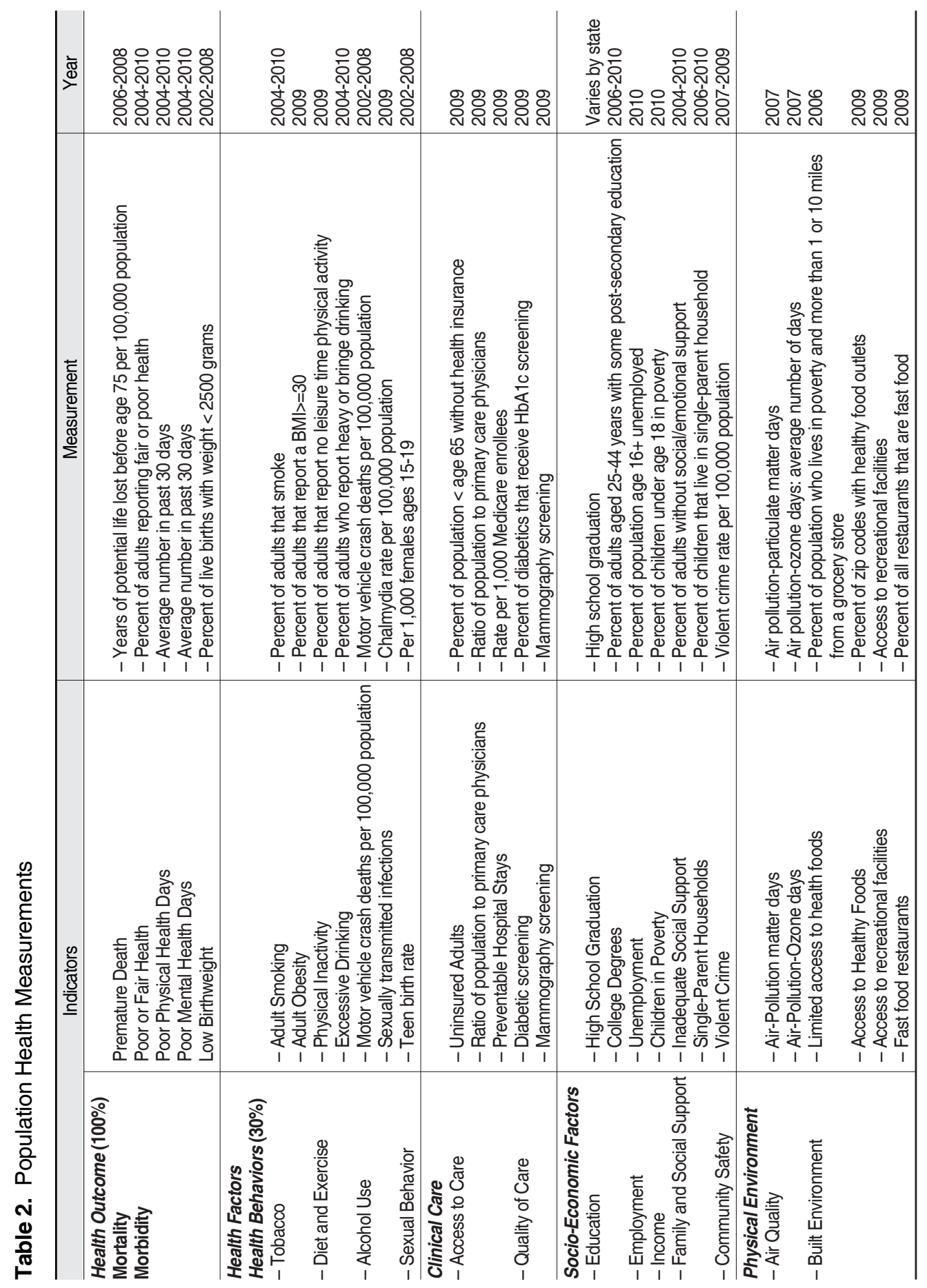


Table 3. Data Measurement and Descriptive Statistics

\begin{tabular}{l|r|r|r|r|r}
\hline \multicolumn{1}{c|}{ Variable } & Obs & Mean & Std. Dev & Min & Max \\
\hline $\begin{array}{l}\text { Dependent Variable } \\
\text { - The Adoption of Comprehensive Plan }\end{array}$ & 162 & \multicolumn{1}{c}{.364} & .482 & 0 & 1 \\
\hline Independent Variables & & & & & \\
- Political Institution Reformed County Government & 162 & .802 & .399 & 0 & 1 \\
- Health Outcomes & & & & & \\
1) Mortality & 162 & -.259 & .421 & -1.16 & .9 \\
2) Morbidity & 162 & -.139 & .316 & -.98 & .69 \\
- Health Factors & & & & & \\
1) Health Behavior & 162 & -.074 & .203 & -.55 & .39 \\
2) Clinical Care & 162 & -.033 & .105 & -.3 & .25 \\
3) Socioeconomic Status & 162 & -.138 &. .253 & -.74 & .5 \\
4) Physical Environment & & & .048 & -.11 & .19 \\
- Subset of Physical Environment & 162 & .005 & .046 & -.08 & .23 \\
1) Air Quality & 162 & -.010 & .037 & -.09 & .19 \\
2) Built Environment & & & & & \\
- Subset of Air Quality & 162 & -.02 & 1.01 & -1.14 & 6.93 \\
1) Air Pollution Matter Days & 162 & .381 & 1.27 & -1.53 & 4.3 \\
\hline 2) Air Pollution- Ozone Days & & & & \\
\hline
\end{tabular}

It is the health data that determined the county unit of analysis for the study. Although the APA survey collected data from municipalities other than at the county level, the county is the unit at which reliable health indicators are collected and is the smallest unit with nationally reliable and comparable health statistics. Costich and Patton (2011) attest that the overall well-being of the county-wide population depends heavily on the county government and public health infrastructure.

A total of 254 counties responded to the APA survey. Counties were dropped from the sample if the county responded to two surveys and the answers differed or if data was missing. Counties remained in the sample if the county responded twice and the responses were identical. This resulted in a sample of $n=162$. Table 4 displays the frequency of county responses in the 34 states represented.

Table 4. Number of County Governments Observed in Each State

\begin{tabular}{l|c||l|c}
\hline \multicolumn{1}{c|}{ State } & Number of Counties & State & Number of Counties \\
\hline Alabama & 1 & Florida & 13 \\
Arizona & 3 & Georgia & 11 \\
California & 19 & Hawaii & 1 \\
Colorado & 2 & Idaho & 1 \\
Delaware & 1 & Illinois & 3 \\
\hline
\end{tabular}




\begin{tabular}{l|c||l|c}
\hline \multicolumn{1}{c|}{ State } & Number of Counties & \multicolumn{1}{c|}{ State } & Number of Counties \\
\hline Indiana & 7 & New Mexico & 3 \\
lowa & 1 & New Jersey & 4 \\
Kansas & 1 & New York & 1 \\
Maryland & 6 & Ohio & 8 \\
Maine & 1 & Oregon & 5 \\
Michigan & 7 & Pennsylvania & 10 \\
Minnesota & 6 & South Carolina & 8 \\
Missouri & 2 & Utah & 5 \\
Montana & 1 & Virginia & 10 \\
Mississippi & 1 & Washington & 1 \\
North Carolina & 15 & Wisconsin & 1 \\
Nevada & 2 & Wyoming & 1 \\
\hline
\end{tabular}

\section{Data Diagnostics}

A variance inflation factor (VIF) test was conducted on the independent variables to investigate potential mulitcollinearity issues. The results of VIF test indicate that mean VIF was below 10 (table 5). This shows there is no collinearity problem with the sets of models.

Table 5. Collinearity Diagnostics (Variance Inflation Factor [VIF])

\begin{tabular}{|c|c|c|c|c|c|c|c|c|c|}
\hline \multirow{2}{*}{ Variables } & Model 1 & Model 2 & Model 3 & Model 4 & Model 5 & Model 6 & Model 7 & Model 8 & Model 9 \\
\hline & VIF & VIF & VIF & VIF & VIF & VIF & VIF & VIF & VIF \\
\hline $\begin{array}{l}\text { Form of Government } \\
\text { (Reformed County) }\end{array}$ & 1.00 & 1.00 & 1.05 & 1.03 & 1.01 & 1.06 & 1.04 & 1.03 & 1.06 \\
\hline $\begin{array}{l}\text { Health Outcomes } \\
\text { 1. Mortality } \\
\text { 2. Morbidity }\end{array}$ & 1.00 & 1.00 & & & & & & & \\
\hline $\begin{array}{l}\text { Health Factors } \\
\text { 1. Health Behavior } \\
\text { 2. Clinical Care } \\
\text { 3. Socio-Economic Status } \\
\text { 4. Physical Environment } \\
\text { 4-1) Air Quality } \\
\text { - Air pollution } \\
\text { - Air Pollution-Ozone } \\
\text { Matter Days } \\
\text { - Built Environment }\end{array}$ & & & $\begin{array}{l}1.92 \\
1.42 \\
1.98 \\
1.11\end{array}$ & $\begin{array}{l}1.37 \\
1.35 \\
1.10\end{array}$ & $\begin{array}{l}1.31 \\
1.31 \\
\\
1.11\end{array}$ & $\begin{array}{l}2.09 \\
1.60 \\
2.30 \\
\\
1.10\end{array}$ & $\begin{array}{l}1.59 \\
1.37 \\
1.10\end{array}$ & $\begin{array}{l}1.41 \\
1.48 \\
\\
1.07\end{array}$ & $\begin{array}{l}2.10 \\
1.61 \\
2.08 \\
\\
1.17 \\
1.23 \\
1.66\end{array}$ \\
\hline Mean VIF & 1.00 & 1.00 & 1.50 & 1.21 & 1.19 & 1.58 & 1.32 & 1.32 & 1.56 \\
\hline $\begin{array}{l}\text { Pearson chi-square } \\
\text { (Prob>chi2) } \\
\end{array}$ & $\begin{array}{l}112.50 \\
0.4689 \\
\end{array}$ & $\begin{array}{l}99.24 \\
0.5967 \\
\end{array}$ & $\begin{array}{l}162.20 \\
0.3505 \\
\end{array}$ & $\begin{array}{l}159.92 \\
0.3983 \\
\end{array}$ & $\begin{array}{l}162.21 \\
0.3713 \\
\end{array}$ & $\begin{array}{l}161.24 \\
0.3491 \\
\end{array}$ & $\begin{array}{l}161.28 \\
0.3695 \\
\end{array}$ & $\begin{array}{l}161.29 \\
0.3693 \\
\end{array}$ & $\begin{array}{l}162.15 \\
0.3105 \\
\end{array}$ \\
\hline $\begin{array}{l}\text { Hosmer and Lemeshow(8) } \\
\text { (Prob>chi2) }\end{array}$ & $\begin{array}{l}5.70 \\
0.6813\end{array}$ & $\begin{array}{l}7.79 \\
0.4542\end{array}$ & $\begin{array}{l}4.91 \\
0.7673\end{array}$ & $\begin{array}{l}4.88 \\
0.7707\end{array}$ & $\begin{array}{l}6.60 \\
0.5809\end{array}$ & $\begin{array}{l}3.39 \\
0.9073\end{array}$ & $\begin{array}{l}3.64 \\
0.8880\end{array}$ & $\begin{array}{l}10.38 \\
0.2393\end{array}$ & $\begin{array}{l}5.46 \\
0.7073\end{array}$ \\
\hline
\end{tabular}


A Pearson chi-square and Hosmer and Lemeshow goodness-of-fit tests were also performed. Both tests resulted in statistical insignificance, meaning that there were no problems concerning the fit of the models. The correlation matrix (table 6) reveals a number of statistically significant relationships between variables, none of which were unexpected or contrary to theory.

Table 6. Correlation Matrix

\begin{tabular}{|c|c|c|c|c|c|c|c|c|c|c|}
\hline & Mortality & Morbidity & $\begin{array}{l}\text { Health } \\
\text { Behavior }\end{array}$ & $\begin{array}{l}\text { Clinical } \\
\text { Care }\end{array}$ & $\begin{array}{c}\text { Socioeconomic } \\
\text { Status }\end{array}$ & $\begin{array}{c}\text { Physical } \\
\text { Environment }\end{array}$ & $\begin{array}{c}\text { Air } \\
\text { Quality }\end{array}$ & $\begin{array}{c}\text { Built } \\
\text { Environment }\end{array}$ & $\begin{array}{l}\text { Air Pollution } \\
\text { Matter Days }\end{array}$ & $\begin{array}{l}\text { Air Pollution } \\
\text { Ozone Days }\end{array}$ \\
\hline Mortality & 1.0000 & & & & & & & & & \\
\hline Morbidity & 0.7666 & 1.0000 & & & & & & & & \\
\hline $\begin{array}{l}\text { Health } \\
\text { Behavior }\end{array}$ & 0.7384 & 0.6703 & 1.0000 & & & & & & & \\
\hline Clinical Care & 0.4986 & 0.3065 & 0.4601 & 1.0000 & & & & & & \\
\hline $\begin{array}{l}\text { Socioeconomic } \\
\text { Status }\end{array}$ & 0.7638 & 0.6869 & 0.6625 & 0.4830 & 1.0000 & & & & & \\
\hline $\begin{array}{l}\text { Physical } \\
\text { Environment }\end{array}$ & 0.1939 & 0.2613 & 0.2644 & 0.2686 & 0.2544 & 1.0000 & & & & \\
\hline Air Quality & -0.0018 & 0.0918 & -0.0459 & -0.0423 & 0.0935 & 0.6978 & 1.0000 & & & \\
\hline $\begin{array}{l}\text { Built } \\
\text { Environment }\end{array}$ & 0.3521 & 0.3666 & 0.4717 & 0.5047 & 0.3282 & 0.3670 & -0.2321 & 1.0000 & & \\
\hline $\begin{array}{l}\text { Air Pollution } \\
\text { Matter Days }\end{array}$ & 0.0954 & 0.2063 & 0.0050 & -0.0005 & 0.1680 & 0.5669 & 0.7344 & -0.0929 & 1.0000 & \\
\hline $\begin{array}{l}\text { Air Pollution } \\
\text { Ozone Days }\end{array}$ & -0.1568 & -0.1057 & -0.1368 & -0.1139 & -0.0891 & 0.2869 & 0.7418 & -0.3276 & 0.2992 & 1.0000 \\
\hline
\end{tabular}

\section{RESULTS AND CONCLUSIONS}

The results of the logistic regression analysis are presented in nine different models that systematically expand the subsets of health outcome and factor variables (table 6). In all of the models, two of the three factors examined here as integral to a place-based approach to planning and health-political institution and physical environmentwere predictive of the adoption of health provisions in county comprehensive plans.

The findings with respect to reformed county governments support the theory that the tendency of this type of political institutional structure to deliver policy efficiency and effectiveness in community development (Feiock \& Kim, 2001; Fleischmann et al., 1992; Downs, 2005; Orfield, 1998; Park, 1996) also extends to public health. 
Table 7. Logistic Regression on the Adoption of Comprehensive Plan for Public Health

\begin{tabular}{|c|c|c|c|c|c|c|c|c|c|}
\hline \multirow{2}{*}{ Indicators } & Model 1 & Model2 & Model 3 & Model 4 & Model 5 & Model 6 & Model 7 & Model 8 & Model 9 \\
\hline & Coef(SE) & Coef(SE) & Coef(SE) & Coef(SE) & Coef(SE) & Coef(SE) & Coef(SE) & Coef(SE) & Coef(SE) \\
\hline $\begin{array}{l}\text { Form of Govermment } \\
\text { (Reformed County) }\end{array}$ & $.878(.465)^{\star}$ & $.869(.463)^{*}$ & $.888(.476)^{*}$ & $.885(.452)^{\star}$ & $.874(.470)^{*}$ & $.848(.478)^{\star}$ & $.845(.476)^{*}$ & $.830(.474)^{*}$ & $.866(.481)^{*}$ \\
\hline $\begin{array}{l}\text { Health Outcomes } \\
\text { 1. Mortality } \\
\text { 2. Morbidity }\end{array}$ & $.145(.397)$ & $-.076(.532)$ & & & & & & & \\
\hline $\begin{array}{l}\text { Health Factors } \\
\text { 1. Health Behavior } \\
\text { 2. Clinical Care } \\
\text { 3. Socio-Economic Status } \\
\text { 4. Physical Environment } \\
\text { - Air Quality } \\
\text { - Air pollution } \\
\text { - Air Pollution-Ozone } \\
\text { Matter Days } \\
\text {-Built Environment }\end{array}$ & & & $\begin{array}{l}.041(1.161) \\
-1.601(1.90) \\
-.180(.936) \\
7.632(3.65)^{* *}\end{array}$ & $\begin{array}{l}-1.588(1.86) \\
-161(.776) \\
7.643(3.63)^{* *}\end{array}$ & $\begin{array}{l}-083(.962) \\
-1.699(1.83) \\
7.575(3.63)^{* *}\end{array}$ & $\begin{array}{l}.087(1.215) \\
-1.766(2.03) \\
-.295(.955) \\
8.35(3.84)^{* *}\end{array}$ & \begin{tabular}{|l|}
$-1.755(2.02)$ \\
$-256(.784)$ \\
$8.34(3.84)^{* *}$
\end{tabular} & \begin{tabular}{|}
$-.126(.997)$ \\
$-1.941(1.95)$ \\
$8.16(3.79)^{* *}$
\end{tabular} & $\begin{array}{l}.082(1.23) \\
-1.925(2.06) \\
-212(.975) \\
\\
199(.186) \\
.324(.146)^{* *} \\
9.36(5.99)\end{array}$ \\
\hline $\begin{array}{l}\text { Number of Observation } \\
\text { Log Likelihood } \\
\text { LRchi2 } \\
\text { Pseudo R2 } \\
\text { Count R2 } \\
\text { McKelvey and Zvoina R2 }\end{array}$ & \begin{tabular}{|l}
162 \\
-104.2346 \\
4.01 \\
0.018 \\
0.636 \\
0.036
\end{tabular} & $\begin{array}{l}162 \\
-104.2915 \\
3.89 \\
0.018 \\
0.636 \\
0.035\end{array}$ & \begin{tabular}{|l}
162 \\
-101.8412 \\
$8.80^{*}$ \\
0.041 \\
0.667 \\
0.072
\end{tabular} & $\begin{array}{l}162 \\
-101.8419 \\
8.79^{\star} \\
0.041 \\
0.667 \\
0.072\end{array}$ & \begin{tabular}{|l}
162 \\
-101.8599 \\
$8.76^{\star}$ \\
0.0412 \\
0.673 \\
0.072
\end{tabular} & $\begin{array}{l}162 \\
-101.3032 \\
9.87 \\
0.0465 \\
0.673 \\
0.081\end{array}$ & \begin{tabular}{|l|}
162 \\
-101.3058 \\
$9.87^{\star}$ \\
0.0464 \\
0.673 \\
0.081
\end{tabular} & \begin{tabular}{|l|}
162 \\
-101.3510 \\
$9.78^{*}$ \\
0.0460 \\
0.667 \\
0.080
\end{tabular} & \begin{tabular}{|l|}
162 \\
-99.5946 \\
$13.34^{*}$ \\
0.0628 \\
0.698 \\
0.106
\end{tabular} \\
\hline
\end{tabular}

On closer examination of the physical environment variables, we found that it higher levels of air pollution, reflected in the number of ozone action days per year, that were associated with the inclusion of health provisions in comprehensive plans. This may be because ozone action days are often announced to the public, resulting in heightened levels of public awareness about air quality. That air quality is associated with the inclusion of health measures may also be an artifact of local comprehensive plans putting into effect state-level environmental laws for regulating the emissions of carbon dioxide. In the wake of Massachusetts v. Environmental Protection Agency, carbon dioxide has to be controlled and regulated, and in carrying out this legal mandate, local governments may adopt the comprehensive plans including the amelioration of air pollution related to ozone action days.

Social equity, operationalized here by the socio-economic status (SES) variable, was not a significant factor in predicting whether counties included health provisions in their comprehensive plans. Our findings suggest that lower SES communities are more likely to adopt health measures in their plans, but this relationship was not significant. Therefore, equity concerns do not appear to play significant role in counties' deliberations over whether to include health measures in their comprehensive plans. SES was highly correlated to a number of variables supported by current theory (table 5 ), but it does not predict whether a community will includes health provisions in their 
comprehensive plans.

Surprisingly, neither morbidity nor mortality had an effect on whether a county included health provisions in their comprehensive plans. In other words, the level of illness and premature mortality in a community has no influence on whether a community plans to alter the built environment to improve health. This is certainly less worrisome in communities that already enjoy a high level of health and that might be seeking to simply maintain it. It is more worrisome in communities with poor health, since it means that planners and others involved in the comprehensive planning process are being unresponsive to a fundamental community need.

\section{DISCUSSION}

This research draws attention to local efforts that emphasize sustainable community practices consistent with improving public health. These local governments create comprehensive plans that try to advance inner-community development while at the same time preserving the environment and expanding public health initiatives. In general, our research highlights that it is the willingness of local governments to take into account population health status and the physical environment that results in the coordination of comprehensive plans with public health. That is, the adoption of comprehensive plans for public health improvement is a result of collaborative policy actions on the part of local government. Since health policy by itself cannot address all public health concerns, multiple policy sectors must be coordinated when a local government formulates community development plans.

Expanding on the theoretical implications, we suggest that reformed county governments have an important role to play in the production of health-oriented comprehensive plans. This form of county government tends to pursue certain policies that both satisfy the governmental responsibility to address community needs and seek efficiency. In line with the standard modus operandi of reformed county governments, the practitioners and policy decision makers rationally judge that separation of public health and community development plan brings further costs to the community. They are more likely to integrate health provisions into their community plans because they expect that doing so will save administrative costs, produce collaborative policy actions, yield a harmonized policy goal, and diffuse the benefits of the plan among the entire community.

A reformed structure, especially the council-manager variety, is more likely to think take a long view rather than a short view when it comes to community policy that may affect future community development patterns and population health. 
Although satisfying short-term development interests can increase employment rates and government revenue, these benefits have to be weighed against the costs in the form of environment restoration and population health maladies. As the county government is the principal agent in the delivery of health care, the responsiveness of county leaders is central to public health improvement.

Differences in the physical environment of communities are more likely to explain the variation in the adoption of comprehensive plans for public health than other variables. The aggregated effect of the physical environment is a predictor of which local governments will address public health interests in their comprehensive plan. That is, air quality and built environment crucially impact population health status, and to improve public health, local governments have to first manage the environment. This priority may be linked to the objectives of current land use regulation and management in smart growth and sustainable development. These current interests promote high density and compact development in order to prevent suburban sprawl, which increases population density and traffic congestion, and leads to a low level of connection between home and workplaces. That is, green-space preservation and attention to air quality can be ways to encourage smart growth and sustainability as well as community development.

The recognition of the ozone problem is more influential than other factors in the adoption of comprehensive plans for public health improvement. Many local governments are concerned about the energy crisis and about the negative effects climate change might have on public health, and they are deeply committed to addressing these problems, prompting them to not only enact various policies that seek to reduce carbon dioxide emissions and encourage renewable energy but also to adopt comprehensive plans that address public health.

There are at least two possible paths that could to be taken to advance the research we have presented here. The first would be to examine the extent to which those involved in the planning process credit the inclusion of health measures in comprehensive plans to their knowledge of environmental concerns. Our research uncovered associations between heightened air pollution and the inclusion of health measures in comprehensive plans, but it cannot be concluded from this study that an awareness of air pollution was the motivation behind that inclusion. The second would be to study the connection between specific place-based needs and the extent to which these needs are addressed in the plan. This study identified what place-based indicators were associated with comprehensive plans that include health provisions, but it did not show whether those place-based indicators were in fact addressed in the plans. For example, do objectively measured ozone issues translate into measures directly related to controlling ozone or to more general measures designed to promote health? 


\section{REFERENCES}

American Planning Association (APA). 2011. Comprehensive planning for public health: Results of the planning and community health research center survey.

Aytur, S. A., D. A. Rodriquez, K. R. Evenson, D. J. Catellier, \& W. D. Rosamond. 2008. The soicodemographics of land use planning: Relationships to physical activity, accessibility, and equity. Health \& Place, 14(3): 367-385.

Choi, S., S.-S. Bae, S.-W. Kwon, \& R. Feiock. 2010. County limits, policy types and expenditure priorities. American Review of Public Administration, 40(1): 29-45.

Corburn, J. 2009. Toward the healthy city: People, places, and the politics of urban planning. Cambridge, MA: MIT Press.

Costich, J. F., \& D. Patton. 2011. Local legal infrastructure and its association with population health. Paper presented at the annual meeting of the Midwest Political Science Association, Chicago, IL, April 1.

Coutts, C., \& Taylor, C. 2011. Putting the capital "E" environment into ecological models of health. Journal of Environmental Health, 74(4): 26-29.

Cummins, S., S. Curtis, A. V. Diez-Roux, \& S. Macintyre. 2007. Understanding and representing "place" in health research: A relational approach. Social Science and Medicine, 65(9): 1825-1838.

Downs, A. 2005. Smart growth: Why we discuss it more than we do it. Journal of the American Planning Association, 71(4): 367-378.

Duhl, L. J., \& A. K. Sanchez. 1999. Healthy cities and the city planning process: A background document on links between health and urban planning. New York: World Health Organization.

Feiock, R. C., \& J. Kim. 2001. Form of government, administrative organization, and local economic development policy. Journal of Public Administration Research and Theory, 11(1): 29-49.

Fishman, R. 2000. The American planning tradition: Culture and policy. Washington, DC: Woodrow Wilson Center Press.

Fleischman, A., G. Green, \& T. Kwong. 1992. What's a city to do? Explaining differences in local economic development policies. Western Political Quarterly, 45(3): 677-699.

Graham, S., \& P. Healey. 1999. Relational concepts of space and place: Issues for planning theory and practice. European Planning Studies, 7(5): 623-646.

Graham, S., \& S. Marvin. 2001. Splintering urbanism. New York: Routledge.

Gruber, J. 1994. Coordinating growth management through consensus building: Incentives and the generation of social, intellectual, and political capital. Working Paper 617. Berkeley: University of California, Institute of Urban and Regional Development. 
Hancock, T. 1993. The evolution, impact and significance of the health cities/healthy communities movement. Journal of Public Health Policy, 14(1): 5-18.

Haan, M., G. Kaplan, \& T. Camacho. 1987. Poverty and health: Prospective evidence from the Alameda County study. American Journal of Epidemiology, 125(6): 989-998.

Hayden, D. 1997. Power of Place: Urban landscapes as public history. Cambridge, MA: MIT Press.

Healey, P. 1996. Consensus-building across difficult divisions: New approaches to collaborative strategy making. Planning Practice and Research, 11(2): 207-216.

Kelly, E. D., \& B. Becker. 2000. Community planning: An introduction to the comprehensive plan. Washington, DC: Island Press.

Levy, J. 2012. Contemporary urban planning. Upper Saddle River, NJ: Pearson.

Link, B., and J. Phelan. 2000. Evaluating the fundamental cause explanation for social disparities in health. In C. Bird, P. Conrad, \& A. Freemont (eds.), The handbook of medical sociology. 5th ed. (pp. 33-46). Upper Saddle River, NJ: Prentice-Hall.

Macintyre, S., and A. Ellaway. 2000. Ecological approaches: Rediscovering the role of the physical and social environment. In L. Berkman, \& I. Kawachi (eds.), Social epidemiology (pp. 332-348). Oxford: Oxford University Press.

Macintyre, S., A. Ellaway, \& S. Cummins. 2002. Place effects on health: How can we conceptualise, operationalise and measure them? Social Science \& Medicine, 55(1): 125-139.

Marmot, M., \& G. Wilkinson. 1999. Social determinants of health. Oxford: Oxford University Press.

Minkler, M., S. P. Wallace, \& M. McDonald. 1995. The political economy of health: A useful theoretical tool for health education practice. International Quarterly of Health Education, 15(2): 111-125.

Mishler, E. G. 1981. Viewpoint: Critical perspectives on the biomedical model. In E. G. Mishler, L. R. Amara Singham, S. T. Hauser, R. Liem, S. D. Osherson, \& N. E.Waxler (eds.), Social contexts of health, illness, and patient care (pp. 1-24). New York: Cambridge University Press.

Molotch, H. 1976. The city as a growth machine: Toward a political economy of place. American Journal of Sociology, 82(2): 309-332.

Moore, C. 1986. The negotiation process: Practical strategies for resolving conflict. San Francisco: Jossey-Bass.

Neuman, M. 1998. Does planning need the plan? Journal of the American Planning, 64(2): 208-220.

Orfield, M. 1998. Metropolitics: A regional agenda for community and stability. Washington, DC: Brookings Institution Press.

Park, K. O. 1996. Determinants of county government growth. In D. C. Menzel \& J. P. 
Thomas (eds.), The American county (pp. 33-52). Tuscaloosa: University of Alabama Press.

Park, S.-C., J.-W. Park, \& K.-H. Lee. 2012. Growth management priority and land use regulation in local governments: Regarding full structural equation modeling. International Review of Public Administration, 17(1): 124-147.

Percival, G. L., M. Johnson, \& M. Neiman. 2009. Representation and local policy: Relating county-level public opinion to policy outputs. Political Research Quarterly, 62(1): 164-177.

Portney, K. 2003. Taking sustainable cities seriously: Economic development, the environment, quality of life in American cities. Cambridge, MA: MIT Press.

Price, C., \& P. Dube. 1997. Sustainable development and health: Concepts, principles and framework for action for European cities and towns. European Sustainable Development and Health Series, No 1. Copenhagen: World Health Organization.

Putnam, R. 1993. Making democracy work: Civic traditions in modern Italy. Princeton, NJ: Princeton University Press.

Raphael, D. 2006. Social determinants of health: Present status, unanswered questions, and future directions. International Journal of Health Services, 36(4): 651-677.

Renner, T. 2001. The local government management profession at century's end. In International City/County Management Association (ed.), Municipal year book. Washington, DC: International City/County Management Association.

Rosen, G. 1993. A history of public health. Exp. ed. Baltimore, MD: Johns Hopkins University Press.

Sallis, J., Owen, N., \& Fisher, E. 2008. Ecological models of health behavior. In K. Glanz, B. Rimer, \& K. Viswanath (eds.), Health behavior and education: Theory, research, and practice (pp. 465-485). San Francisco: Wiley.

Schively, Carissa. 2007. Integrating health into comprehensive planning. Design for Health series, August.

Svara, J. H. 1990. Official leadership in the city: Patterns of conflict and cooperation. New York: Oxford University Press.

Talen, E. 1998. Visualizing fairness: Equity maps for planners. Journal of the American Planning Association, 64(1): 22-38.

Tesh, S. 1990. Hidden Arguments: Political ideology and disease prevention policy. New Brunswick, NJ: Rutgers University Press.

Yen, I. H., and Syme S. L. 1999. The social environment and health: A discussion of the epidemiologic literature. Annual Review of Public Health, 20: 287-308.

Young, T. K. 2006. Population health: Concepts and methods. New York: Oxford University Press. 